\title{
Health promotion of nursing staff in hospital environments
}

\author{
A promoção da saúde da equipe de enfermagem no âmbito hospitalar
}

\section{La promoción de la salud del personal de enfermería en el ámbito hospitalario}

Laura Andrian Leal ${ }^{1}$, Silvia Helena Henriques Camelo ${ }^{1}$, Fernanda Ludmilla Rossi Rocha ${ }^{1}$, Thamiris Cavazzani Vegro $^{1}$, Fabiana Cristina dos Santos ${ }^{1}$

Objective: to analyze the scientific evidence of the strategies adopted by hospitals aimed at promoting the health of nursing workers. Methods: integrative review with data collected in electronic databases: Medline, Lilacs, Scielo, BDENF, Scopus and CINAHL, with the descriptors: Strategies; hospitals; Nursing and Health Promotion Team. Results: there were 18 articles selected and the analysis allowed to find organizational strategies to promote the health of nursing workers as prevention of biological risks, the use of personal protective equipment, among others. Conclusion: strategies for health promotion are possible as necessary and they should be reconsidered by managers and professionals working in hospitals in order to promote the quality of working life.

Descriptors: Strategies; Hospitals; Health Promotion; Nursing, Team.

Objetivo: analisar as evidências científicas das estratégias adotadas pelas instituições hospitalares que visam à promoção da saúde dos trabalhadores de enfermagem. Métodos: revisão integrativa, cuja coleta de dados realizada em bases de dados eletrônicas: Medline, Lilacs, Scielo, BDENF, Scopus e CINAHL, tendo como descritores: Estratégias; Hospitais; Promoção da Saúde e Equipe de Enfermagem. Resultados: foram selecionados 18 artigos e a análise permitiu encontrar estratégias organizacionais para a promoção da saúde do trabalhador de enfermagem como: prevenção a riscos biológicos, o uso de equipamentos de proteção individual, entre outras. Conclusão: estratégias para a promoção da saúde tanto são possíveis quanto necessárias e, portanto, devem ser repensadas por gestores e profissionais que atuam nas instituições hospitalares a fim de promover a qualidade de vida no trabalho.

Descritores: Estratégias; Hospitais; Promoção da Saúde; Equipe de Enfermagem.

Objetivo: analizar las evidencias científicas de las estrategias adoptadas por hospitales destinados a promover la salud de los trabajadores de enfermería. Métodos: revisión integradora, con recolección de datos en las bases de datos electrónicas: Medline, Lilacs, Scielo, BDENF, Scopus y CINAHL, cuyos descriptores fueron: Estrategias; Hospitales; Promoción de la Salud y Personal de Enfermería. Resultados: 18 artículos fueron seleccionados y el análisis permitió encontrar estrategias de organización para promover la salud de los trabajadores de enfermería, como prevención de riesgos biológicos, uso de equipo de protección personal, entre otros. Conclusión: estrategias para promoción de la salud, tanto son posibles cuanto son necesarias y, por lo tanto, deben ser reconsideradas por gestores y profesionales que trabajan en hospitales con el fin de promover la calidad de vida laboral.

Descriptores: Estrategias; Hospitales; Promocíon de la Salud; Grupo de Enfermería.

${ }^{1}$ Escola de Enfermagem de Ribeirão Preto, Universidade de São Paulo. Ribeirão Preto, SP, Brazil.

Corresponding author: Laura Andrian Leal

Escola de Enfermagem de Ribeirão Preto. Universidade de São Paulo. Avenida dos Bandeirantes, 3900 - Campus Universitário - Monte Alegre. CEP: 14040-902. Ribeirão Preto, SP, Brazil. E-mail: laura.andrian.leal@usp.br 


\section{Introduction}

Health promotion is defined from the Ottawa Charter in 1986 as a community training process to improve its quality of life and health. In this document five fields of action are identified: healthy public policy construction, supportive environments for health creation, skills development, community action strengthen and health services reorientation ${ }^{(1)}$.

Thus, health promotion is inserted in the model of care perspective seeking quality of life of the population, leading to the need for actions directed to different health care areas, including those developed within the hospitals.

The hospital as part of health services, must be committed to the care planning for the occurrence of health promotion. However, the practice within these institutions needs to be rethought, because of its complex organizational structure, both to the roles of professionals, the division of labor, hierarchy, and in the rules that govern it.

The role of nursing in this scenario is focused on the management of services and its activities are guided by rigid structures and routine functions ${ }^{(2)}$, and it is characterized by fragmentation of tasks. The nursing staff (nurses, technicians and assistants) are the main care vehicle and attention to patients, and their services provided face the huge challenge of ensuring quality care, assuming various roles and responsibilities. Even in this context, it is seen little value in working conditions, being essential to worker's health ${ }^{(3)}$.

Thus, it is clear that the nursing professionals encounter several risks that may interfere with their health, such as emotional factor, due to the interaction with difficult situations, with pressures on their day-to-day physical wear, psychosocial risks, among others ${ }^{(4)}$. From this context, the hospital should implement measures to promote the safety and health of workers in order to reduce or control the situations of risks.
Worker's health is essential to the development of any hospital organization. However, it is observed that more and more institutions charge higher employee productivity without offering them favorable conditions ${ }^{(5)}$.

It is believed that the hospital should establish strategies to mitigate possible risks that may affect the health of workers, specifically, the nursing team, which corresponds to a significant number within the organization. The adoption of preventive measures to facilitate the promotion of health workers must ensure their health, preventing accidents and workrelated diseases ${ }^{(6)}$. In this regard, we can highlight the Regulatory Standard 32 which is responsible for defining the measures to protect the safety and health of health services workers, or those performing promotion and health care activities, such as measures to biological risks, using insurance equipment, aprons, among others ${ }^{(7)}$.

In the hospital scenario, some strategies are considered effective for the health of nursing workers, such as: to guide professionals about the risk factors of the hospital and of the activities performed; to encourage the use of Personal Protective Equipment; to ergonomically fit the physical spaces and furniture; to use methods to improve the relationship and communication intra and inter teams, among others ${ }^{(8)}$.

It is worth noting that the management process of the institution may interfere in the organization and quality of life of the nursing staff, for example, the dimensioning of nursing personnel, exchange of schedules, vacations, licenses and subsequent adjustments. The dimensioning of nursing staff aims to make better use of human resources, contributing to improve the quality of care. Among other measures, work schedules that allocate enough nurses for the units, development of supervision and minimization of work overload, represent actions related to the appropriate personnel dimensioning ${ }^{(9)}$.

Thus, there are several possibilities of strategies to promote the health of the nursing staff. The 
challenge is to implement them in an institution where the physical, structural and bureaucratization adopted are factors that hinder interventions to change.

Faced with these perspective, we have the following question: What are the strategies used by hospital organizations that promote the health of nursing workers mentioned in the literature?

Characterizing the strategies developed in hospitals that benefit the health of the nursing team, should contribute to cause reflection of future professionals who intend to work in this area, the risks they must face daily, as well as provide insight to managers of these organizations in the implementation of better working conditions for the safety and health of its employees.

This study aimed to analyze the scientific evidence of the strategies adopted by hospitals aimed at promoting the health of nursing workers.

\section{Method}

This study used the integrative review method, which consists of wide literature review on a specific topic, aiming to build a synthesis of studies carried out separately, and investigating similar problems ${ }^{(10-11)}$.

The study preparation steps were: elaboration of the guiding question, establishment of the objectives of the review and inclusion and exclusion criteria of the articles; definition of information to be extracted from the research; selection of articles in the literature; analysis of results; discussion of findings and presentation of the review ${ }^{(12)}$.

The search strategy by the studies was consulting the electronic databases: Medical Literature Analysis and Retrieval System Online (Medline), Latin American and Caribbean Health Sciences - Lilacs, Scientific Electronic Library Online - SciELO, Enfermagem- Base BDENF, Cumulative INDX to Nursing and Allied Helth Literature - SCOPUS and CINAHL Database. For studies selection, we use a script with a table identifying the authors, journal title, year of publication, work objectives, level of scientific evidence and key findings of the articles.

Data collection took place between January and July 2014 and the literature used the descriptors in Health Sciences: Strategies; Hospitals; Nursing staff and Health Promotion, and these descriptors also in English and Spanish. The criteria used for the selection of the sample were: articles published in national and international journals, in Portuguese, English and Spanish, in the last five years, available in full on the selected databases and to answer the guiding research question: What are the strategies used by hospital organizations that promote the health of nursing workers mentioned in the literature?

By using the last five years, we seek to highlight the recent literature available in electronic databases, considering the Regulatory Standard 32, published in 2005 and updated in 2011, which gives instructions and safety measures that should be adopted by organizations for health professionals. Articles not answering this question were excluded.

As steps to select the articles, the articles were first analyzed based on the title and abstract, and after reading in full ${ }^{(13-14)}$, the publications were separated who responded to the goals and guiding question of our study, thus making the final sample.

\section{Results}

The analysis of electronic databases allowed to identify, initially, a total of 25 articles, of which seven indexed in the Medline database, four in Lilacs, seven in Scielo, two in BDENF, three in CINAHL and two in Scopus.

Thus, 18 articles were selected (Figure 1). 


\begin{tabular}{|c|c|c|c|}
\hline Authors & Journals/Year & Objectives & Main strategies \\
\hline Dalmolin et $\mathrm{al}^{(15)}$ & Rev Enferm UERJ/2009 & $\begin{array}{l}\text { How nursing experiences dilemmas and } \\
\text { moral suffering in professional practice. }\end{array}$ & $\begin{array}{l}\text { Actions that value the professional dialogue, } \\
\text { organization of work and materials. }\end{array}$ \\
\hline $\begin{array}{l}\text { Naumanem, } \\
\text { Liesivuori }^{(16)}\end{array}$ & Public Health Nurs/2009 & $\begin{array}{l}\text { Describe activities in the workplace of } \\
\text { nurses and their working environment. }\end{array}$ & $\begin{array}{l}\text { Prevention for biological risks, hygienic measures, } \\
\text { education and administration. }\end{array}$ \\
\hline Nunes et $\mathrm{al}^{(17)}$ & Online Braz J Nurs/2009 & $\begin{array}{l}\text { Identifying the nurse's view of health } \\
\text { promotion in hospitals. }\end{array}$ & $\begin{array}{l}\text { Training in infection control, disease prevention, } \\
\text { treatment and cure of diseases. }\end{array}$ \\
\hline Giomo et $\mathrm{al}^{(18)}$ & Rev Enferm UERJ/2009 & $\begin{array}{l}\text { Identifying accidents at work, } \\
\text { absenteeism and occupational risks } \\
\text { related with absenteeism in nursing staff. }\end{array}$ & $\begin{array}{l}\text { Investment in hospitals in accident prevention in } \\
\text { workers. }\end{array}$ \\
\hline Pereira et $\mathrm{al}^{(19)}$ & $\begin{array}{l}\text { Rev Pesqui Cuid } \\
\text { Fundam/2009 }\end{array}$ & Identifying stressors in nursing work. & $\begin{array}{l}\text { Creation of institutional spaces and hazardous } \\
\text { materials suitability. }\end{array}$ \\
\hline Bonini et $\mathrm{al}^{(20)}$ & Rev Eletr Enferm/2009 & $\begin{array}{l}\text { Characterizing the professionals who } \\
\text { suffered occupational accidents with } \\
\text { biological material. }\end{array}$ & $\begin{array}{l}\text { Availability of personal protective equipment and } \\
\text { staff vaccination. }\end{array}$ \\
\hline Marzialeetall ${ }^{(21)}$ & Rev Bras Enferm/2010 & $\begin{array}{l}\text { Evaluating the proposed interactive } \\
\text { training such as changing strategics for } \\
\text { the behavior of workers in the proper } \\
\text { use of gloves. }\end{array}$ & $\begin{array}{l}\text { Provision of personal protective equipment, } \\
\text { gloves. Offering education programs to biological } \\
\text { risks. }\end{array}$ \\
\hline $\begin{array}{l}\text { Custódio et } \\
\mathrm{al}^{(22)}\end{array}$ & Rev Enferm UERJ/2010 & $\begin{array}{l}\text { Ascertain the knowledge produced by } \\
\text { Brazilian nursing on workers' health in } \\
\text { master's and doctorate courses 2003- } \\
2007 \text {. }\end{array}$ & $\begin{array}{l}\text { Risk prevention of biological materials, policy } \\
\text { creation of human resources in the organization } \\
\text { and / or management changes. }\end{array}$ \\
\hline Paula et $\mathrm{al}^{(23)}$ & Aquichán/2010 & $\begin{array}{l}\text { Characterizing the working conditions } \\
\text { leading professional of the hospital to } \\
\text { psychological distress. }\end{array}$ & Inclusion of continuing education. \\
\hline Mininel et $\mathrm{al}^{(24)}$ & $\begin{array}{c}\text { Rev Latino-Am } \\
\text { Enfermagem/2011 }\end{array}$ & $\begin{array}{l}\text { Identifying the working process, the } \\
\text { psychic loads and the stresses generated } \\
\text { in nursing workers. }\end{array}$ & $\begin{array}{l}\text { Availability of resources for the organization of } \\
\text { the work process. Organizational structure. }\end{array}$ \\
\hline Vieira et $\mathrm{al}^{(25)}$ & $\begin{array}{l}\text { Rev Latino-Am } \\
\text { Enfermagem/2011 }\end{array}$ & $\begin{array}{l}\text { Evaluating occupational accidents with } \\
\text { exposure to biological material, as well } \\
\text { as the profile of the nursing staff. }\end{array}$ & $\begin{array}{l}\text { Provision of personal protective equipment, } \\
\text { prevention of biological risks and establishing } \\
\text { educational programs. }\end{array}$ \\
\hline $\begin{array}{l}\text { Mosadeghar et } \\
\mathrm{al}^{(26)}\end{array}$ & $\begin{array}{l}\text { Health Serv Manage } \\
\text { Res/2011 }\end{array}$ & $\begin{array}{l}\text { Getting a better understanding of the } \\
\text { relationship between job stress and } \\
\text { quality of life of employees work. }\end{array}$ & $\begin{array}{l}\text { Implementation of stress management training } \\
\text { programs, improved environmental organization. }\end{array}$ \\
\hline $\begin{array}{l}\text { Vagharseyyedin } \\
\text { et } \mathrm{al}^{(27)}\end{array}$ & Nurs Health Sci/2011 & $\begin{array}{l}\text { Describing the experiences of Ukrainian } \\
\text { nurses regarding their quality of working } \\
\text { life. }\end{array}$ & $\begin{array}{l}\text { Providing opportunities to advance knowledge } \\
\text { and organization of hospitals. }\end{array}$ \\
\hline Rickard, et al $^{(28)}$ & Collegian/2012 & $\begin{array}{l}\text { Assess the impact of an organizational } \\
\text { intervention that aims to reduce the } \\
\text { stress in hospital nurses. }\end{array}$ & $\begin{array}{l}\text { Creation of policies working conditions, resilient } \\
\text { organizational system, and changes in the } \\
\text { organizational system. }\end{array}$ \\
\hline Lee et $\mathrm{al}^{(29)}$ & Int J Public Health/2012 & $\begin{array}{l}\text { Examining the development of health } \\
\text { promotion in the health care workplace. }\end{array}$ & $\begin{array}{l}\text { Proportioning alignment healthy service } \\
\text { strategies and offering courses to control stress. }\end{array}$ \\
\hline Martins et $\mathrm{al}^{(30)}$ & $\begin{array}{l}\text { Rev Latino-Am } \\
\text { Enfermagem/2012 }\end{array}$ & $\begin{array}{l}\text { Describing accidents at work in a hospital } \\
\text { in northern Portugal and analyze its } \\
\text { main impact in 2008-2010 period. }\end{array}$ & $\begin{array}{l}\text { Provision of personal protective equipment, } \\
\text { implementation of educational policies and } \\
\text { monitoring of occupational risks. }\end{array}$ \\
\hline Toffano, et $\mathrm{al}^{(31)}$ & Acta Paul Enferm/2012 & $\begin{array}{l}\text { Describing and comparing the adherence } \\
\text { to standard precautions scores of nurses. }\end{array}$ & $\begin{array}{l}\text { Offering training classes for nursing staff in } \\
\text { preventing accidents. }\end{array}$ \\
\hline Silva, et $\mathrm{al}^{(32)}$ & $\begin{array}{c}\text { Rev Latino-Am } \\
\text { Enfermagem/2013 }\end{array}$ & $\begin{array}{l}\text { Proposing intervention strategies for the } \\
\text { health of hospital-based nurses. }\end{array}$ & $\begin{array}{l}\text { Prevention of biological risks, control measures, } \\
\text { hygiene, occupational biosafety and promotion } \\
\text { ofleisure activities daily. }\end{array}$ \\
\hline
\end{tabular}

Figure 1 - Distribution of articles found, according to authors, level of evidence, main hospital strategies to promote health of the nursing staff 
Selected articles were published from 2009 to 2013, in journals of national and international circulation, with 10 articles in English and eight in Portuguese.

Analyzing the research designs, we identified six articles using the qualitative methodological approach, 11 using quantitative studies and one with qualitative and quantitative approach. Among the studies that used the qualitative methodological approach, the most commonly used types were descriptive and exploratory; and from the quantitative, the most commonly used types are: Descriptive, retrospective, intervention, comparative and transversal.

After collecting data and analyzing the studies found, we can discuss the results in a great theme: "Strategies of hospital organizations for the promotion of nursing workers health and the point of view of this professionals".

Data showed strategies that can be implemented in hospital for safety and promotion of workers' health as prevention of biological risks and accidents; Control measures related to occupational biosafety; organization of the work process, changes in organizational structure and management of the institution; provision of personal protective equipment; creation of human resources policies; provide safe and suitable cutting materials; investment in actions that value the professional dialogue; realignment of incentive strategies for staff training and inclusion of continuing education.

Studies have also shown that nursing workers have the vision of the institution's participation in the implementation of measures to promote health, especially those related to working conditions, establishment of institutional spaces, availability of courses and social support to workers.

\section{Discussion}

Nursing professionals are subjected to various risks in the workplace, such as: physical, biological, chemical, and others, demonstrating the importance of establishing health promotion measures, through educational strategies or organizational changes and favoring accidents reduction or occupational diseases in these workers.

Strategies for prevention and control of risks and/or injuries from physical and psychological overloads must be designed and implemented by the hospitals in order to promote the health of nursing workers $^{(16,22,32)}$. In this sense, it is relevant, the adoption of intervention measures on the organizational structure in order to increase job control and adjust the psychological levels of demand ${ }^{(32)}$.

Prevention of biological risks is another important thing in the studies, and control strategies are directly related to a diversity of knowledge, involving hygiene, occupational biosafety, as well as education, administration, engineering and $\operatorname{law}^{(16,22,32)}$, being important that institutions develop and incorporate preventive measures involving all these aspects in order to provide health and disease prevention for workers.

The need for hospitals to invest in the prevention of accidents is essential because the hospital has a complex work environment, often aggressive to the integrity of the nursing staff, who may get sick due to the type of activity performed ${ }^{(18)}$.

The notification of accidents, mainly involving biological material, is an important prevention strategy, for the analysis and dissemination of these data contributing to adoption of control measures by the institution, and greater supervision of the one responsible, reducing injuries to health professionals $^{(33)}$.

Regarding to mental and mechanical overloads, one of the intervention focus should be the provision of institutional resources that minimize wear consequential of these overload, making efforts to organize the work process. Rethinking the organizational structure of health services in the worker's perspective, it is effectively faced with several workloads to be the focal point of interventionist proposals for hospitals ${ }^{(24)}$. 
From this perspective, skilled nursing professionals should feel co-responsible and encouraged to incorporate preventive measures for the promotion of their health, focused on organizational structure as well as those directed to themselves.

Risk management related to the work of hospital nurse, for example, the provision of Personal Protective Equipment by institutions and investment in their use, such as use of gloves, disposable aprons, mask and other equipment, are considered extremely important for preventing exposure of biological materials, providing greater security to the professionals. In addition, the appropriate materials disposal, vaccination, including joint actions established between workers and management services, with the aim of improving working conditions, especially those related to their organization, and the creation of educational programs are aimed strategies by researchers to promote the health of the nursing team $^{(20-21,25,30)}$.

Authors highlighted that many workers of the hospital are with incomplete vaccination against hepatitis $\mathrm{B}$, being it necessary that health services monitor the immunization of employees, since, among the three addressed infections, hepatitis B is the only preventable vaccine ${ }^{(33)}$.

The promotion of sports and leisure activities on the job by employers are some beneficial measures for workers' social life ${ }^{(34)}$, helping to reduce stressors that can cause physical and emotional stress of the professional in the workplace.

The implementation of human resources policy in the organization and/or a change in more flexible management style, to promote professional growth and safety of employees ${ }^{(35)}$, and growth and security opportunities offered by hospitals are directly associated to job satisfaction ${ }^{(22,35)}$.

It is known that hospitals remain playing extremely important roles in providing health care, considering the scope of activities offered there. It is a complex organization and depends on the articulation of actions, occurring the integration of the work of many professionals. In this sense, the organization must implement tools that allow better management of its human capital, and some of them should be aimed at promoting the health of their workers, especially the nursing staff, being big quantity of staff in the sector.

The investment in actions by healthcare organizations that value the dialogue, recognition, respect, encouragement, stimulating personal and professional development of nursing staff, should enable integration among workers, supervisors and managers ${ }^{(15)}$. Thus, these strategies should help to improve interpersonal communication and labor relationships, minimizing possible sufferings of professionals.

The organization must also be attentive to the lifestyle of workers, which interferes favorably or not in the development of health problems at work. Thus, the adoption of health promotion measures can happen at various times, by the realignment of health services strategies, the greater availability of resources and through programs of the institution as a result of changes in the organizational work model ${ }^{(29)}$.

Other strategies observed in hospitals is the adoption of measures such as new formulations of administrative policies for managing the health of nursing workers, the implementation of free health monitoring programs to employees, maintaining a supportive environment for worker and offering medical services ${ }^{(26,29)}$.

The hospital initiative implementing programs such as stress management training and assistance programs to the server, should be used to help wear reduction on the workers, thus offering better quality of life for the nursing staff, and the policies implementation of work conditions and a positive psychosocial climate of security ${ }^{(26,28)}$.

In this sense, social support can be seen as a strategy for health of nursing staff and when promoted by the institution. it must establish improvement of social relationships and provide useful information on work activities, assisting in the physical and 
mental health of individuals, acting as moderator of occupational diseases and contributing to reducing uncertainties in contingency situations ${ }^{(36)}$.

Permanent learning is another strategy highlighted by researchers to promote healthy work environment in order to achieve equity in care through educational proposals that motivate the search for self-knowledge and professional development ${ }^{(20,23,25)}$.

In addition to the institutional role in the implementation of strategies for ensuring the health of workers and the view of some scholars, the promotion of health of nursing staff in the hospital may occur through individual initiatives, that is from the professionals themselves, where they seek their training in infection control, development of technical skills and preparation of integrated plans ${ }^{(17)}$.

Thus, it is relevant to encourage nursing staff to incorporate activities into their daily lives that prevent or reduce risk in the workplace.

The awareness of their work process and the resulting wear contribute to the scientific knowledge acquisition in the prevention of health problems and promote the strengthening of the category to fight for better conditions of work and life $\mathrm{f}^{(37)}$.

It is recognized that the institution has a key role in promoting the health of nursing workers, as they can benefit through the humanization of care, reducing excessive costs, decreasing absenteeism at work, increasing the well-being and health of employees to adjust the working conditions in the hospital ${ }^{(38)}$, improving the management of the unit and promoting quality of service.

In spite of the strategies mentioned above, the current situation found in most hospitals is ignorance and sometimes non-implementation of measures to promote health and safety for the staff, operating in an environment considered complex, stressful, with high demand for care and conditions to worsen their health. It is important in this case that quality of life programs and continuing education tools to the nursing staff may be offered by the institutions, so that changes in professional practice and organization of work contribute to promoting health and ensuring quality of working life of these individuals.

There is evidence showing that the professionals of the nursing team recognize the need to create institutional spaces where subjects can verbalize feelings of anxiety, dissatisfaction, insecurity and conflict, experienced in dealing with patients, with the work team and with the institution, in a feedback process $^{(19)}$.

Professionals point out to be responsibility of the institution to promote their health and safety at work, and spaces for training groups are some of the options for these professionals. It is expected that the nursing staff has the opportunity to show their potential and limitations, interacting with other workers in the work environment, minimizing possible stress factors or conditions unsuitable work conditions that may contribute to their illness.

In the current context of the health sector, the biggest challenge pointed out is the process of reorganization of services to ensure distribution and use of human resources that address the effectiveness, efficiency, and economy of the health system. In the case of nursing professionals, they have a responsibility to provide care to patients and to do so, they need to have, in addition to human resources, skilled labor conditions and in quantities that enable them to respond to the institutional expectations.

In this sense, the nursing staff thinks institutions leaders should take care to implement measures to update or hold courses in order to improve the knowledge of their employees, promoting adherence to safety measures in the workplace to minimize the risks transmission of pathogens such as, for example, adherence to the standard precautions ${ }^{(31)}$.

Nursing staff are separated during their work in the institutions, with various situations involving their physical and psychological health, and should be prepared from the academic background to establish their own strategies to defend the risks found in this environment, so that the maintaining the balance of their health is preserved from situations that can lead 
to injuries or occupational diseases.

In this perspective, nurses point out that adequate social services; opportunities to advance knowledge through permanent learning strategies; safety; interpersonal and organizational relationships of institutions are measures beneficial to the worker's well-being(27) and should be encouraged by the organization itself, since it reflects in the quality of care and satisfaction of the work performed.

Therefore, prevention strategies for accidents or occupational diseases, shall include joint actions established between workers and management services, and need to be focused on improving working conditions, mainly directed to the organization's service, offering safe materials, the implementation of educational programs, and awareness of the changing behavior of both workers, such as managers, since isolated actions are considered ineffective to minimize such injuries ${ }^{(25)}$.

After collecting data and analyzing the studies found, we can discuss the results in a great theme: "Strategies of hospital organizations for the promotion of nursing workers health and the point of view of this professionals".

Data showed strategies that can be implemented in hospital for safety and promotion of workers' health as prevention of biological risks and accidents; Control measures related to occupational biosafety; organization of the work process, changes in organizational structure and management of the institution; provision of personal protective equipment; creation of human resources policies; provide safe and suitable cutting materials; investment in actions that value the professional dialogue; realignment of incentive strategies for staff training and inclusion of continuing education.

Studies have also shown that nursing workers have the vision of the institution's participation in the implementation of measures to promote health, especially those related to working conditions, establishment of institutional spaces, availability of courses and social support to workers.

\section{Discussion}

Nursing professionals are subjected to various risks in the workplace, such as: physical, biological, chemical, and others, demonstrating the importance of establishing health promotion measures, through educational strategies or organizational changes and favoring accidents reduction or occupational diseases in these workers.

Strategies for prevention and control of risks and/or injuries from physical and psychological overloads must be designed and implemented by the hospitals in order to promote the health of nursing workers $^{(16,22,32)}$. In this sense, it is relevant, the adoption of intervention measures on the organizational structure in order to increase job control and adjust the psychological levels of demand ${ }^{(32)}$.

Prevention of biological risks is another important thing in the studies, and control strategies are directly related to a diversity of knowledge, involving hygiene, occupational biosafety, as well as education, administration, engineering and law $(16,22,32)$, being important that institutions develop and incorporate preventive measures involving all these aspects in order to provide health and disease prevention for workers.

The need for hospitals to invest in the prevention of accidents is essential because the hospital has a complex work environment, often aggressive to the integrity of the nursing staff, who may get sick due to the type of activity performed ${ }^{(18)}$.

The notification of accidents, mainly involving biological material, is an important prevention strategy, for the analysis and dissemination of these data contributing to adoption of control measures by the institution, and greater supervision of the one responsible, reducing injuries to health professionals $^{(33)}$.

Regarding to mental and mechanical overloads, one of the intervention focus should be the provision of institutional resources that minimize wear consequential of these overload, making 
efforts to organize the work process. Rethinking the organizational structure of health services in the worker's perspective, it is effectively faced with several workloads to be the focal point of interventionist proposals for hospitals ${ }^{(24)}$.

From this perspective, skilled nursing professionals should feel co-responsible and encouraged to incorporate preventive measures for the promotion of their health, focused on organizational structure as well as those directed to themselves.

Risk management related to the work of hospital nurse, for example, the provision of Personal Protective Equipment by institutions and investment in their use, such as use of gloves, disposable aprons, mask and other equipment, are considered extremely important for preventing exposure of biological materials, providing greater security to the professionals. In addition, the appropriate materials disposal, vaccination, including joint actions established between workers and management services, with the aim of improving working conditions, especially those related to their organization, and the creation of educational programs are aimed strategies by researchers to promote the health of the nursing team $^{(20-21,25,30) \text {. }}$

Authors highlighted that many workers of the hospital are with incomplete vaccination against hepatitis $\mathrm{B}$, being it necessary that health services monitor the immunization of employees, since, among the three addressed infections, hepatitis B is the only preventable vaccine $\mathrm{e}^{(33)}$.

The promotion of sports and leisure activities on the job by employers are some beneficial measures for workers' social life ${ }^{(34)}$, helping to reduce stressors that can cause physical and emotional stress of the professional in the workplace.

The implementation of human resources policy in the organization and/or a change in more flexible management style, to promote professional growth and safety of employees ${ }^{(35)}$, and growth and security opportunities offered by hospitals are directly associated to job satisfaction ${ }^{(22,35)}$.
It is known that hospitals remain playing extremely important roles in providing health care, considering the scope of activities offered there. It is a complex organization and depends on the articulation of actions, occurring the integration of the work of many professionals. In this sense, the organization must implement tools that allow better management of its human capital, and some of them should be aimed at promoting the health of their workers, especially the nursing staff, being big quantity of staff in the sector.

The investment in actions by healthcare organizations that value the dialogue, recognition, respect, encouragement, stimulating personal and professional development of nursing staff, should enable integration among workers, supervisors and managers ${ }^{(15)}$. Thus, these strategies should help to improve interpersonal communication and labor relationships, minimizing possible sufferings of professionals.

The organization must also be attentive to the lifestyle of workers, which interferes favorably or not in the development of health problems at work. Thus, the adoption of health promotion measures can happen at various times, by the realignment of health services strategies, the greater availability of resources and through programs of the institution as a result of changes in the organizational work model ${ }^{(29)}$.

Other strategies observed in hospitals is the adoption of measures such as new formulations of administrative policies for managing the health of nursing workers, the implementation of free health monitoring programs to employees, maintaining a supportive environment for worker and offering medical services ${ }^{(26,29)}$.

The hospital initiative implementing programs such as stress management training and assistance programs to the server, should be used to help wear reduction on the workers, thus offering better quality of life for the nursing staff, and the policies implementation of work conditions and a positive psychosocial climate of security ${ }^{(26,28)}$. 
In this sense, social support can be seen as a strategy for health of nursing staff and when promoted by the institution. it must establish improvement of social relationships and provide useful information on work activities, assisting in the physical and mental health of individuals, acting as moderator of occupational diseases and contributing to reducing uncertainties in contingency situations ${ }^{(36)}$.

Permanent learning is another strategy highlighted by researchers to promote healthy work environment in order to achieve equity in care through educational proposals that motivate the search for self-knowledge and professional development ${ }^{20,23,25)}$.

In addition to the institutional role in the implementation of strategies for ensuring the health of workers and the view of some scholars, the promotion of health of nursing staff in the hospital may occur through individual initiatives, that is from the professionals themselves, where they seek their training in infection control, development of technical skills and preparation of integrated plans ${ }^{(17)}$.

Thus, it is relevant to encourage nursing staff to incorporate activities into their daily lives that prevent or reduce risk in the workplace.

The awareness of their work process and the resulting wear contribute to the scientific knowledge acquisition in the prevention of health problems and promote the strengthening of the category to fight for better conditions of work and life ${ }^{(37)}$.

It is recognized that the institution has a key role in promoting the health of nursing workers, as they can benefit through the humanization of care, reducing excessive costs, decreasing absenteeism at work, increasing the well-being and health of employees to adjust the working conditions in the hospital ${ }^{(38)}$, improving the management of the unit and promoting quality of service.

In spite of the strategies mentioned above, the current situation found in most hospitals is ignorance and sometimes non-implementation of measures to promote health and safety for the staff, operating in an environment considered complex, stressful, with high demand for care and conditions to worsen their health. It is important in this case that quality of life programs and continuing education tools to the nursing staff may be offered by the institutions, so that changes in professional practice and organization of work contribute to promoting health and ensuring quality of working life of these individuals.

There is evidence showing that the professionals of the nursing team recognize the need to create institutional spaces where subjects can verbalize feelings of anxiety, dissatisfaction, insecurity and conflict, experienced in dealing with patients, with the work team and with the institution, in a feedback process $^{(19)}$.

Professionals point out to be responsibility of the institution to promote their health and safety at work, and spaces for training groups are some of the options for these professionals. It is expected that the nursing staff has the opportunity to show their potential and limitations, interacting with other workers in the work environment, minimizing possible stress factors or conditions unsuitable work conditions that may contribute to their illness.

In the current context of the health sector, the biggest challenge pointed out is the process of reorganization of services to ensure distribution and use of human resources that address the effectiveness, efficiency, and economy of the health system. In the case of nursing professionals, they have a responsibility to provide care to patients and to do so, they need to have, in addition to human resources, skilled labor conditions and in quantities that enable them to respond to the institutional expectations.

In this sense, the nursing staff thinks institutions leaders should take care to implement measures to update or hold courses in order to improve the knowledge of their employees, promoting adherence to safety measures in the workplace to minimize the risks transmission of pathogens such as, for example, adherence to the standard precautions ${ }^{(31)}$.

Nursing staff are separated during their work in the institutions, with various situations involving 
their physical and psychological health, and should be prepared from the academic background to establish their own strategies to defend the risks found in this environment, so that the maintaining the balance of their health is preserved from situations that can lead to injuries or occupational diseases.

In this perspective, nurses point out that adequate social services; opportunities to advance knowledge through permanent learning strategies; safety; interpersonal and organizational relationships of institutions are measures beneficial to the worker's well-being $^{(27)}$ and should be encouraged by the organization itself, since it reflects in the quality of care and satisfaction of the work performed.

Therefore, prevention strategies for accidents or occupational diseases, shall include joint actions established between workers and management services, and need to be focused on improving working conditions, mainly directed to the organization's service, offering safe materials, the implementation of educational programs, and awareness of the changing behavior of both workers, such as managers, since isolated actions are considered ineffective to minimize such injuries ${ }^{(25)}$.

\section{Conclusion}

The hospitals by their complexity of the actions developed inside, have different aspects that distanced sometimes the proposal for promoting the health of its workers, constituting a challenge for professionals who work in these care spaces, as well as, its directors and managers.

The study found the health promotion strategies related to work organization which stood out preventive actions to the physical and psychological burdens, the use of Personal Protective Equipment, the creation of human resource policies and changes in the organizational structure of the institution. In this perspective, the nursing staff also highlighted the role of the organization in the implementation of strategies for promotion of their health such as: creation of institutional spaces for professionals verbalize their feelings; updating and completion of courses to improve knowledge, changes in management of the organization and offering social support.

Changes in beliefs/culture and philosophy of institutions/services and its professionals are necessary and possible for the promotion of health professionals in hospital scenarios, and actions taken in this regard may lead the individual in search of a quality of life.

The strategies offered by hospitals and the view of nursing team professionals regarding these behaviors are aspects that should be rethought by hospital managers and nurses in order to provoke thought that health promotion actions both are possible as needed in this organizational context and strategies developed in this regard may lead the professional seeking high quality of working life, with consequences for the promotion of health service of patients.

\section{Colaborations}

Leal LA, Camelo SHH, Rocha FLR, Vegro TC and Santos FC contributed for planning and Project elaboration, analysis, data interpretation, article edition and final approval of the version to be published.

\section{References}

1. Ministério da Saúde (BR). Secretaria de Políticas de Saúde. Projeto Promoção da Saúde. As cartas da Promoção da Saúde. Série B. Textos Básicos em Saúde, Brasília: Ministério da Saúde; 2002.

2. Backes DS, Backes MS, Souza FGM, Erdmann AL. 0 papel do enfermeiro no contexto hospitalar: a visão de profissionais de saúde. Cienc Cuid Saúde. 2008; 7(3):319-26. 
3. Araújo AKF, Ferreira AS, Paone LD, Silva RP, Ventura MR. Estresse dos graduandos de enfermagem trabalhadores de uma unidade de terapia intensiva. Consc Saúde. 2008; 7(3):391-6.

4. Amestoy SC, Schwartz E, Trofehrn MB. A humanização do trabalho para os profissionais de enfermagem. Acta Paul Enferm. 2006; 19(4):444-9.

5. Aguiar ADF. Saúde do trabalhador de enfermagem que atua em centro de saúde. Rev Inst Cienc Saúde. 2009; 27(2):103-8.

6. Marziale MHP, Jesus LH. Modelos explicativos e de intervenção na promoção da saúde do trabalhador. Acta Paul Enferm. 2008; 21(4):654-9.

7. Ministério do Trabalho e Emprego (BR). Portaria GM n.o 1.748, de 30 de agosto de 2011. Dispõe sobre atualização da norma regulamentadora № 32. [Internet]. 2011 [citado 2015 jan 5]. Disponível em: http://www.normaslegais.com. br/legislacao/portaria-mte-1748-2011.htm

8. Silva DMPP, Marziale MHP. Condições de trabalho versus absenteísmo-doença no trabalho de enfermagem. Ciênc Cuid Saúde. 2006; 5(supl):166-72.

9. Nicola AL, Anselmi ML. Dimensionamento de pessoal de enfermagem em um hospital universitário. Rev Bras Enferm. 2005; 58(2):186-90.

10. Barbosa LR, Melo MRAC. Relações entre qualidade da assistência de enfermagem: revisão integrativa da literatura. Rev Bras Enferm. 2008; 61(3):36670 .

11. Mendes KDS, Silveira RCCP, Galvão CM. Revisão integrativa: método de pesquisa para a incorporação de evidências na saúde e na enfermagem. Texto Contexto Enferm. 2008; 17(4):758-64.

12. Souza MT, Silva MD, Carvalho R. Revisão integrativa: o que é e como fazer. Einstein [Internet]. 2010 [citado 2012 abr 27]; 8:102-6. Disponível em: http://apps.einstein.br/revista/arquivos/PDF/ 1134-Einsteinv8n1_p102-106_port.pdf

13. Liberato SMD, Souza AJG, Gomes ATL, Medeiros LP, Costa IKF, Torres GV. Relação entre adesão ao tratamento e qualidade de vida: revisão integrativa da literatura. Rev Eletr Enf. [Internet]. 2014 [citado 2014 ago 25]; 16(1):191-8. Disponível em: https://www.fen.ufg.br/fen_revista/v16/n1/ pdf/v16n1a22.pdf
14. Medeiros LP, Souza MBC, Sena JF, Melo MDM, Costa JWS, Costa IKF. Roy Adaptation Model: integrative review of studies conducted in the light of the theory. Rev Rene. 2015; 16(1):132-40.

15. Dalmolin GL, Lunardi VL, Filho WDL. O sofrimento moral dos profissionais de enfermagem no exercício da profissão. Rev Enferm UERJ. 2009; 17(1):35-40.

16. Naumanen P, Liesivuori J. Workplace health promotion activities of Finnish occupational health nurses. Public Health Nurs. 2009; 26(3):218-28.

17. Nunes JM, Martins KL, Nóbrega MFB, Souza MA, Fernandes AFC, Vieira NFC. Promoting health in the hospital from the viewpoint of the nurse: descriptive-exploratory study. Online Braz J Nurs [Internet] 2009 [cited 2014 Aug 25]; 8(3). Available from: http://www.objnursing.uff.br/ index.php/nursing/article/view/2568

18. Giomo DB, Freitas FCT, Alves LA, Robazzi MLCC. Acidentes de trabalho, riscos ocupacionais e absenteísmo entre trabalhadores de enfermagem hospitalar. Rev Enferm UERJ. 2009; 17(1):24-9.

19. Pereira CA, Miranda LCS, Passos JP. O estresse ocupacional da equipe de enfermagem em setor fechado. Rev Pesqui Cuid Fundam Online. [Internet]. 2009 [citado 2014 ago 25]; 1(2):196-202. Disponível em: http://www.seer.unirio.br/index. php/cuidadofundamental/article/view/346/331

20. Bonini AM, ZevianCP, Facchin LT, Gir E, Canini SRMS. Exposição ocupacional dos profissionais de enfermagem de uma unidade de terapia intensiva a material biológico. Rev Eletr Enferm. [Internet]. 2009 [citado 2014 jan 25]; 11(3):65864. Disponível em: www.fen.ufg.br/revista/v11/ n3/pdf/v11n3a25.pdf

21. Marziale MH, Zapparoli AS, Felli VE, Anabuki MH. Rede de prevenção de acidentes de trabalho: uma estratégia de ensino a distancia. Rev Bras Enferm. 2010; 63(2):250-6.

22. Custódio IL, Moreira TMM, Lima FET, Freitas MC, Lima MMR, Silva AL. Saúde do trabalhador: caracterização das dissertações e teses nacionais de enfermagem, 2003-2007. Rev Enferm UERJ. 2010; 18(4):604-9.

23. Paula GS, Reis JF, Dias LC, Dutra VFD, Braga ALS, Cortez EA. 0 sofrimento psíquico do profissional de enfermagem da unidade hospitalar. Aquichán. 2010; 10(3):267-79. 
24. Mininel VA, Baptista PCP, Felli VE. Psychic workloads and strain process in nursing workers of Brazilian university hospitals. Rev Latino-Am Enfermagem. 2011; 19(2):340-7.

25. Vieira M, Padilha MT, Pinheiro RDC. Analysis of accidents with organic material in health workers. Rev Latino-Am Enfermagem. 2011; 19(2):332-9.

26. Mosadeghrad AM, Ferlie E, Rosenberg D. A study of relationship between job stress, quality of working life and turnover intention among hospital employees. Health Serv Manage Res. $2011 ; 24(4): 170-80$.

27. Vagharseyyedin SA, Vanaki Z, Mohammadi E. Quality of work life: experiences of Iranian nurses. Nurs Health Sci. 2011; 13(1):65-75.

28. Rickard G, Lenthall S, Dollard M, Opie T, Knight $S$, Dunn $S$, et al. Organisational intervention to reduce occupational stress and turnover in hospital nurses in the Northern Territory, Australia. Collegian. 2012; 19(4):211-21.

29. Lee CB, Chen MS, Chu CMY. The health promoting hospital movement in Taiwan: recent development and gaps in workplace. Int J Public Health. 2012; 58(2):313-7.

30. Martins MDS, Silva NAP, Correia TIG. Accidents at work and its impact on a hospital in Northern Portugal. Rev Latino-Am Enfermagem. 2012; 20(2):217-25.

31. Toffano SEM, Santos CB, Canini SRMS, Galvão MTG, Brevidelli MM, Gir E. Adherence to standard precautions by nursing professionals in a university hospital. Acta Paul Enferm. 2012; 25(3):401-7.
32. Silva MS, Baptista PCP, Felli VEA, Martins AC, Sarquis LMM, Mininel VA. Interventions strategies for the health of university hospital nursing staff in Brazil. Rev Latino-Am Enfermagem. 2013; 21(1):300-8.

33. Julio RS, Filardi MBS, Marziale MHP. Acidentes de trabalho com material biológico ocorridos em municípios de Minas Gerais. Rev Bras Enferm. 2014; 67(1):119-26.

34. Silva-Costa A, Griep RH, Fischer FM, Rotenberg L. Need for recovery from work and sleep-related complaints among nursing professionals. Work. 2012; 41(Suppl 1):3726-31.

35. Figueiredo IM, Neves DS, Montanari D, Camelo SHH. Qualidade de vida no trabalho: percepções dos agentes comunitários de equipes de saúde da família. Rev Enferm UERJ. 2009; 17(2):262-7.

36. Andrade T, Hoch RES, Vieira KM, Rodrigues CMC. Síndrome de burnout e suporte social no trabalho: a percepção dos profissionais de enfermagem de hospitais públicos e privados. Organ Soc. 2012; 19(61):231-51.

37. Machado LSF, Rodrigues EP, Oliveira LMM, Laudano RCS, Sobrinho CLN. Agravos à saúde referidos pelos trabalhadores de enfermagem em um hospital público da Bahia. Rev Bras Enferm. 2014; 67(5):684-91.

38. Ministério da Saúde (BR). Política nacional de humanização. Humaniza SUS. Brasília: Ministério da Saúde; 2005. 